\title{
Erratum to: CCN3: the-pain-killer inside me
}

\section{Bernard Perbal}

Published online: 12 July 2012

(C) The International CCN Society 2012

\section{Erratum to: J Cell Commun Signal}

DOI 10.1007/S12079-012-0163-5

We would like to clarify the following:

The CCN Society was inadvertently mentioned in the author list in the following paper:

CCN3: the-pain-killer inside me

By Bernard Perbal

Bernard Perbal is the sole author of this paper.

Springer wishes to apologize for any inconvenience caused.

Springer, 2012.

The online version of the original article can be found at http://dx.doi.org/ 10.1007/S12079-012-0163-5.

B. Perbal $(\bowtie)$

International CCN Society,

Paris, France

e-mail: bperbal@gmail.com 